\title{
LUKUTAIDON MONET KASVOT
}

Unesco on julistanut vuoden 1990 kansainväliseksi lukutaitovuodeksi. Moni voi tietysti ajatella, että mitäpä se meille suomalaisille kuuluu, meillähän osaavat jo kaikki lukea ja kirjoittaa. Maailmassa vallitseva lukutaidottomuus koskettaa kuitenkin myös meitä suomalaisia, koska nykymaailmassa ei kukaan voi ummistaa silmiään muun maailman ongelmilta ja epäoikeudenmukaisuuksilta. Teollistuneiden maiden hyvinvointia ei voida perustaa enää kehitysmaiden riistolle, kuten tähän asti on tehty. Myös niille on annettava tilaisuus kehittyä ja vaurastua. Peruslukutaito on tämän kehityksen välttämätön edellytys ja lähtökohta. Myös yleisinhimillinen oikeudenmukaisuus ja humanistinen ihmiskäsitys lähtee siitä, että jokaisella yksilöllä tulee olla oikeus oppimiseen ja itsensä kehittämiseen. Eri maissa ja yhteiskunnissa tämä ajatus toteutuu toistaiseksi hyvin eri tavoin kuten tämän lehden artikkeleista käy ilmi.

Lukutaidon opettamiseen sisältyy monenlaisia ristiriitoja. Vaikka suuri osa kehitysmaiden sivistyneistöstä on innolla mukana lukutaitokampanjoissa, niin kaikki vallanpitäjät eivät näe väestön lukutaidon parantamista tärkeäksi, koska se voi horjuttaa heidän asemaansa. Myös lukutaitokampanjoiden liittäminen osaksi laajempaa yhteiskunnallista reformipolitiikkaa saattaa kohdata parempiosaisten vastustusta. Kehittyneiden maiden käynnistämiä lukutaitokampanjoita syytetään usein kulttuuri-imperialismista, eikä aina syyttä. Meillä länsimaisen kultuurin edustajilla on taipumus väheksyä muita, lähinnä suulliseen traditioon perustuvia kulttuureja, kuten Tuomas Takala artikkelissaan aiheellisesti toteaa. Lukutaitokampanjoiden tulisi perustua niin pitkälle kuin mahdollista paikallisen väestön omalle kulttuuritraditiolle, eikä vieraan kulttuurin pakkosyötölle.

Meidän on syytä muistaa, että olimme itse noin sata vuotta sitten suunnilleen samassa kehitysvaiheessa, missä moni Aasian, Afrikan ja Latinalaisen-Amerikan kehitysmaa on tällä hetkellä. Nykyisillä kehitysmailla on oltava oikeus kehittää kulttuuriaan omista lähtökohdistaan, kuten olemme itse saaneet tehdä. Paitsi kansojen oman kehityksen kannalta on lukutaidolla huomattava merkitys myös maailmanlaajuisesti. Ellei lukutaito ja sitä kautta yleinen tietoisuus globaalisista ympäristö-, väestö-ja muista ongelmista ja niiden vaatimista toimenpiteistä leviä kaikkiin maihin, voivat seuraukset olla katastrofaaliset.

Myös teollistuneissa maissa puutteellinen lukutaito on edelleen merkittävä yhteiskunnallinen ongelma. OECD:n arvion mukaan kehittyneissä maissa on 50 miljoonaa lukutaidotonta, näistä 23 
miljoonaa Yhdysvalloissa. Lukutaidottomuus on yleisintä näissä maissa siirtolaisten ja pakolaisten keskuudessa, mutta yllättävän paljon sitä esiintyy myös alkuperäisväestön keskuudessa.

Meillä peruslukutaidottomuutta ei juuri esiinny. Tästä syystä lukutaidolle onkin Suomessa asetettava korkeammat vaatimukset. Pelkkä mekaaninen lukutaito ei riitä, vaan on edellytettävä myös tekstin syvällisempää ymmärtämistä. Jyväskylän yliopistossa 1970-luvulla tehdyn tutkimuksen mukaan osalla peruskoululaisia havaittiin tekstinymmärtämisessä vakavia puutteita. Oppilaat kykenivät kyllä tekstin pinnalliseen, toistavaan ymmärtämiseen, mutta päätelmien tai kriittisten arvioiden tekeminen tekstin pohjalta näytti kaipaavan kohentamista. Ymmärtäminen on varmaankin noista ajoista parantunut, mutta ei ole mitään syytä kuvitella, että ongelma olisi kokonaan poistunut. Vastaavia tutkimuksia aikuiset keskuudessa ei ole meillä tehty. Arkihavaintojen perusteella näyttää siltä, että aikuistenkaan tekstin ymmärtäminen ei ole aina kovin syvällistä. Asia vaatisi tarkempaa tutkimista.

Kansalaisten lukutaidon parantamista on vaadittu eri maissa hyvinkin erilaisista intresseistä lähtien. Idealistiset kansansivistäjät ovat nähneet lukutaidossa keinon auttaa vähempiosaisia parantamaan asemaansa yhteiskunnassa. Tähän on liittynyt usein myös kansallinen identiteetin herättäminen ja oman kansallisvaltion luominen, kuten meillä Suomessa tapahtui viime vuosisadan lopulla. Kirkko oli jo tätä aikaisemmin lujittanut asemaansa opettamalla kansaa lukemaan uskonnollista kirjallisuutta. Uludet poliittiset vallanpitäjät ovat nähneet erityisesti kehitysmaissa lukutaidossa keinon oman valtansa vahvistamiseen. Teknokraatit ovat puolestaan vaatineet kansan perussivistyksen kohottamista taloudellisista tehokkuusvaatimuksista lähtien.

Lukutaito kelpaa siis moneen käyttöön. Sillä voidaan alistaa ja sopeuttaa ihmisiä erilaisiin ideologisiin käytäntöihin. Toisaalta se voi olla kuitenkin myös todellinen apuväline ihmisten oman tietoisuuden laajentamisessa ja elämän hallinnassa. Ei siis ole olemassa mitään neutraalia lukutaitoa, vaan lukutaito on aina sidoksissa joihinkin yhteiskunnallisiin käytäntöihin ja arvoihin. On kuitenkin huomattava, että vaikka lukutaitoa on levitetty ja juurrutettu kansan keskuuteen hyvinkin kapeista lähtökohdista, niin se on saanut aikaan lähes aina myös muunlaista ajattelua. Ainakin osa ihmisistä on siirtynyt jossain vaiheessa mekaanisesta opinkappaleiden tankkaamisesta asioiden omakohtaiseen ja kriittiseen arviointiin. Tässä on juuri lukutaidon vallankumouksellinen voima. Eli kuten Marja Leena Toukonen toteaa artikkelissaan, "lukutaito on eräs identiteettiämme muokkaava tekijä, tiedon ja yhteiskunnallisen vallan osa”. 